\title{
IMPACTS OF HYDROMETEOROLOGICAL EXTREMES IN THE BOHEMIAN-MORAVIAN HIGHLANDS IN 1706-1889 AS DERIVED FROM TAXATION RECORDS
}

\begin{abstract}
DOLÁK, L., BRÁZDIL, R., VALÁŠEK, H. (2015): Impacts of hydrometeorological extremes in the Bohemian-Moravian Highlands in 1706-1889 as derived from taxation records. Geografie, 120 , No. 4, pp. 465-488. - Taxation records related to tax relief for farmers whose livelihoods were affected by hydrometeorological extremes (HMEs) on seven estates in the Bohemian-Moravian Highlands (Moravia) in the 1706-1889 period are used to study the impacts of HMEs on the socio-economic situation of the farmers. The impacts of HMEs are here classified into agricultural production, material property and the socio-economic situation of individual farmers. Direct impacts took the form of losses of property, supplies and farming equipment, and also of bad yields, depletion of livestock and damage to fields and meadows. Simple lack of income, debt, impoverishment, reduction in livestock and deterioration in field fertility were among the longer-term effects. The impacts are discussed with respect to approaches to mitigation of the negative effects of HMEs and to the problems associated with obtaining support and in terms of a hierarchy of consequent impacts. The paper embodies a methodological approach for analysis of HMEs impacts in South Moravia in the $17^{\text {th }}-19^{\text {th }}$ centuries.

KEY WORDS: hydrometeorological extremes - taxation records - damage - impacts Bohemian-Moravian Highlands.

The article was prepared with the aid of financial support from research project MUNI/A/0952/2013 "Analysis, evaluation, and visualization of global environmental changes in the landscape sphere" (L. Dolák) and from the Grant Agency of the Czech Republic, grant reference 13-19831S "Hydrometeorological extremes in South Moravia derived from documentary sources in the $17^{\text {th }}-20^{\text {th }}$ centuries" (R. Brázdil, H. Valášek).
\end{abstract}

\section{Introduction}

Disastrous hydrometeorological extremes have a significant influence on society. They are a real threat to human life, both directly and in the longer term, and do great material damage. While the majority of related studies focus on their analysis in hydrological or meteorological terms, systematic study of their impacts is less frequent. This is partly related to the availability (or otherwise) of the kind of data upon which such studies might be based, especially if the time scale is extended a number of centuries into the past.

Quite close descriptions of the impacts of past hydrometeorological extremes may be found in the documentary evidence used as basic data in historical climatology, a study that aims, among other things, to address "the vulnerability of past societies and economies to climate variations, climate extremes 
and natural disasters" (Brázdil et al. 2005). However, as mentioned by Pfister (2010), studies of the impacts of climate variations on past societies remain quite marginal relative to the mainstream of historical climatology. Many past hydrometeorological extremes, particularly in the pre-instrumental period, were recorded solely because of their various impacts. This is important not only for standard investigation into them, but also for study of the impacts themselves. The taxation data associated with local accountancy and governmental financial records constitute documentary sources of particular value (Pfister 2001; Brázdil et al. 2005, 2010; Pfister et al. 2008).

Despite the considerable geographical scope and potential of taxation records, they have been employed for these purposes relatively rarely on an international scale. If there has been any particular emphasis, it has tended towards using past tax data for climate reconstructions involving, for example, temperatures (Leijonhufvud, Wilson, Moberg 2008; Kiss, Wilson, Bariska 2011; Wetter, Pfister 2011), precipitation (García et al. 2003) and ice winter severity index (Luterbacher et al. 2010). Some time ago, Grove and Battagel (1983) took a slightly different approach and analysed taxation data to investigate climate impacts on farming in the Sunnfjord Fogderi region (western Norway) where a unified tax system based on numbers of wintering stock, quantities of seed sown and cereals harvested was introduced in 1670. An enormous number of requests for tax relief in $\mathrm{AD}$ 1667-1723 indicated a deterioration of farming conditions in the path of burgeoning glaciers, when farms at higher altitudes were affected by landslides and avalanches and at lower altitudes by floods.

Particular attention has been paid to analysis of the hydrometeorological extremes indicated in Czech taxation records. For example, Matušíková (1996) analysed the consequences of four floods of the River Elbe for the Poděbrady estate in Bohemia in the second half of the $17^{\text {th }}$ century by means analysing associated administrative processes. Brázdil and Valášek (2003), working on Pernštejn estate records for 1694-1718, clarified the bureaucratic approaches to assessment of the damage done by hydrometeorological extremes, appraised their human impacts, described the varying nature of the damage, and assessed its extent. Brázdil, Valášek, Sviták (2003) studied hydrometeorological extremes on the Dolní Kounice and Mikulov estates in 1650-1849, with some emphasis on description of individual events and their consequences. Knowledge of hydrometeorological extremes for the above estates, with an element of extension to others, has been summarised by Brázdil, Valášek, Chromá (2006). A series of papers have addressed the spatio-temporal variability of hydrometeorological extremes for various groups of estates located in several parts of southern Moravia: the Bítov estate in the 1771-1848 period (Zahradníček 2005); the Veselí nad Moravou estate 1784-1849 (Chromá 2011); ten estates in south-eastern Moravia 1751-1900 (Brázdil et al. 2012); the Brtnice, Třebíc and Velké Meziříčí estates, 1706-1849 (Dolák, Brázdil, Valášek 2013); and five estates in south-western Moravia 1761-1900 (Chromá et al. 2013). More recently, taxation data for 201 estates in South Moravia were used to analyse floods in the 1652-1941 period (Brázdil et al. 2014a) and hailstorms from 1650 to 1941 (Brázdil et al. 2014b).

Because previous papers have tended to focus on analysis of the hydrological or meteorological aspects of hydrometeorological extremes, this study turns to 
their impact on the socio-economic situation of farmers, using taxation data for seven estates located in the Bohemian-Moravian Highlands in the 1706-1889 period. This means that the goal of this study is to show in detail the different types of impact that can be derived from this particular type of documentary evidence (taxation data), to categorise them and draw attention to their further consequences in agricultural life. It will also create a methodology that addresses these matters in a broader manner. The following section describes the area studied and the taxation system in Moravia. Section 3 is devoted to taxation records and the methods used for their interpretation and analysis. The impacts of hydrometeorological extremes on agriculture, property and society are presented in Section 4. The next section discusses the results obtained and is followed by concluding remarks.

\section{Area and taxation system}

\subsection{The area}

The area studied is located in the central part of the Bohemian-Moravian Highlands and consists of seven estates in the land registers: Brtnice, Budišov, Křižanov, Osová, Petráveč, Třebíč and Velké Meziř́ičí, as defined in 1849 and published by Voldán et al. (1964; Fig. 1). These estates changed hands fairly frequently, becoming the property of a number of aristocratic families. The Waldstein-Wartenberg family in Třebíč, the Liechtensteins in Velké Meziříćći, the Haugwitzes in Osová and the Collaltos in Brtnice were among the most prominent. Petráveč, belonging to the deanery in Velké Meziřričí, was an exception. In 1849, two major towns (Třebíč and Velké Meziř́íći), ten small towns, 145 villages and four farms were documented in the area studied (Obršlík, Rezníček, Voldán 1966). The total area of all these estates in the mid- $19^{\text {th }}$ century was 70,066 ha. Petráveč (362 ha) was the smallest and Třebíč (20,530 ha) the largest.

The natural conditions in the study area (located at altitudes of 320-710 m) dictate their agricultural classification into a potato-oats production section, especially in the northern and middle part and a potato-growing part in the south and south-east (Budňáková, Jacko 2012). Crops consisted largely of oats, rye, potatoes and, in the floodplains, wheat and barley. Fodder plants, legumes and fodder beet were grown as well. The area also raised cattle and sheep, farmed fish and exploited timber resources (Horák 1961; Ježková, Štarha 1961; Hamerníková 1968).

\subsection{The taxation system}

Hydrometeorological extremes that did damage to crops or property cultivated by estate dependents (often smallholding peasant farmers) gave legitimate grounds for tax relief in the historical past. In order to comprehend the study period in any depth, one must take into account the development of the taxation system, starting in the second half of the $17^{\text {th }}$ century with the 


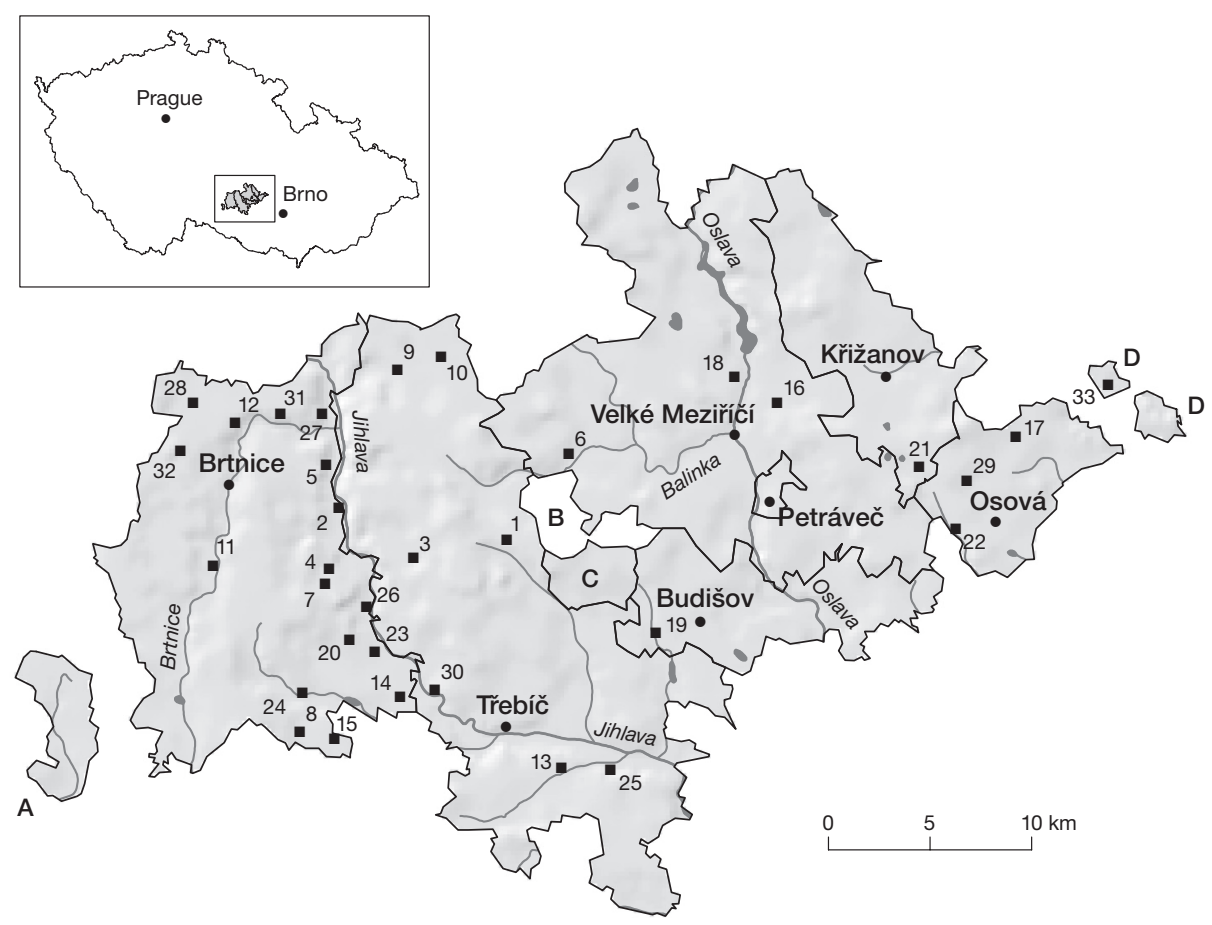

Fig. 1 - The area studied, indicating the cadastral units of the Brtnice, Budišov, Křižanov, Osová, Petráveč, Třebíč and Velké Meziř́ičí estates as of 1849 (A-D identify registrations of more distant estates), and places mentioned in text: 1 - Benetice; 2 - Bransouze; 3 - Červená Lhota; 4 - Číchov; 5 - Dolní Smrčné; 6 - Horní Radslavice; 7 - Hynkov; 8 - Chlístov; 9 - Kamenice; 10 - Kamenička; 11 - Kněžice; 12 - Komárovice; 13 - Kožichovice; 14 - Krahulov; 15 - Markvartice; 16 - Martinice; 17 - Milešín; 18 - Mostiště; 19 - Nárameč; 20 - Okř́išky; 21 - Ořechov; 22 - Osová Bítýška; 23 - Petrovice; 24 - Pokojovice; 25 - Pozdátky; 26 Přibyslavice; 27 - Přímělkov; 28 - Příseka; 29 - Skřinářov; 30 - Sokolí; 31 - Střížov; 32 Uhřínovice; 33 - Víckov

introduction of tax collection based on area and official evaluation, done in person by specialists.

1. The First Moravian Land Registry, 1655: Tallage (tax levied upon farmers) was set by a commission on the basis of three land-value classes. The basic unit was known as the tallage "hide" [lán]. In 1657 the Land Assembly established that "whosoever in the future shall suffer damage due to fire or otherwise, for the purpose of reduction of [taxes due from] hides affected by the damage, [should] report it to the regional administrator who will evaluate it [together] with the neighbours". This also applied in the event of hydrometeorological extremes, although only for "rustic" land (the land of subjects; Novotný 1936).

2. The Second Moravian Land Registry, 1669: This was a revision arising out of inaccuracies and inadequate provisions that emerged in practice of the first registry. However, rustic land remained the only type taxed (Novotný 1959). 
3. The Maria Theresa Land Registry, 1749: The incentive for the creation of the new land registry was an expansion of taxation to include both rustic and "dominical" land (owned by the church or the aristocracy). Work on establishing the cadastral zones started on 30 July 1748 and the resulting proposal for the revision of terms for rustic land was accepted on 9 May 1749. On the basis of a decree issued on 26 July 1748, relief in the event of damage to a house, barn, field or agricultural yield resulting from flood-water or unfavourable weather could be granted for a period of up to three years (Dolák, Brázdil, Valášek 2013). After 1757, a second “Theresian” Land Registry came into force, in which the land of the aristocracy was taxed according to the number and size of the homesteads on the estate. With only a short break in 1789-1790, it remained in force until 1820. The subjects paid one third of gross yield and up to 50\% more than the nobility (Kubačák 1994).

4. The Joseph II Land Registry, 1789: The purpose of Josephian cadastral reform, which was in force from 1 November 1789 to 1 May 1790, was to distribute the taxation more evenly between subjects and nobility. The basic taxation unit was the municipality, the lands of which were surveyed geodetically, but inaccurately. After the repeal of Josephian cadastral reform, the Theresian cadastre was reintroduced, in which the tax liability of both the nobility and subjects was set at an equal amount of 30 gulden [zlatý] and 52 1/5 kreutzer [krejcar] for every hundred gulden of the yield (Šimek 1918).

5. The Theresian-Josephian Land Registry, 1792: From 1792 onwards, the Maria Theresa Land Registry was modified and rustic land tax was paid with respect to the areas and yields of the Joseph II Land Registry, while the nobility was taxed according to the Maria Theresa Land Registry. On 23 April 1819, the Moravian Land Administration established the conditions under which tax relief on land could be considered, as well as any supplementary tax relief that might be claimed by owners of dominical or rustic property damaged by hydrometeorological extreme (circular no. 9575). The amount of relief was based on the extent of land damaged. The regulation came into force on 1 November 1819 (S19). From 1 November 1820 onwards, tax was regulated according to the Register of Land Yield [Matrika pozemku výnosového] which remained in force until the introduction of the Stable Land Registry [Stabilni katastr]. Land tax was set at $16 \%$ of net yield with an additional charge of one-third of this tax (Kocman et al. 1954). On 27 February 1835, decree no. 21819 specified more precisely the conditions for granting relief and also set procedures for the recording officials and investigative commissions (S22).

6. The Stable Land Registry, 1851: On 3 December 1817 Emperor Franz I issued a patent on land tax, leading to the creation of the Stable Land Registry. This arose out of inequalities in the taxation of dominical and rustic lands, growing financial demands of the monarchy, and improvements in the accuracy of tax estimation, making for more efficient collection. New formal cadastral units for Moravia were surveyed and set in 1824-1830 and 1833-1835, establishing the net yield of land according to soil quality classes and crops cultivated. These came into force in 1851, but were quickly outdated. They were revised in 1869-1881, but with no conspicuous improvement (Šimek 1918). 


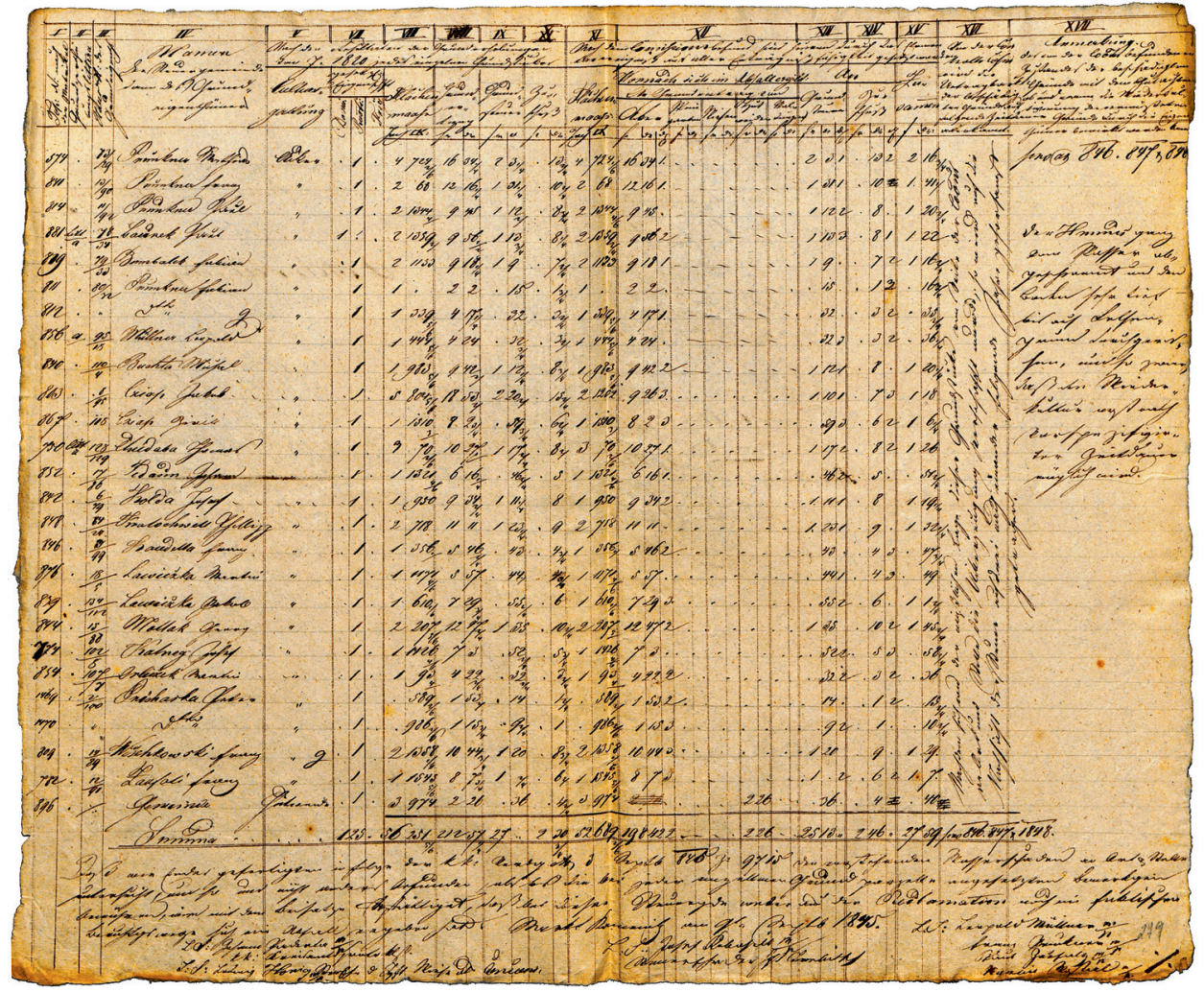

Fig. 2 - Taxation record referring to damage done by a hailstorm on 27 August 1845 in the Kamenice municipality (S30)

In practice, the process of granting tax relief consisted of several steps. If a hydrometeorological extreme led to damage to the fields or property of subjects, a representative of the municipality (magistrate or reeve) reported this in writing to the estate office. A detailed, specific list of damage was drawn up for the damage commission. This was sent to the regional office, where a group of three commissioners was convened to survey the areas affected and to check the damage report in situ (Fig. 2). The resulting protocol was sent to the Moravian Land Administration (Gubernium) in Brno, where a decision was taken on granting or denying tax relief and its duration. This decision was communicated to the estate office which subsequently informed the municipality affected (Brázdil et al. 2012, 2014a, Dolák et al. 2013).

\section{Data and methods}

The whole administrative process that led to tax relief for damage done by hydrometeorological extremes generated a "paper-trail" that created a number of documentary sources for modern researchers. Damage reports are a primary 
source of information for types of extreme, time of occurrence, municipalities affected and the nature of the land damaged. For example, the representatives of the Príseka municipality sent the following report to the estate official in Brtnice on 11 August 1834: "On 9 August this year at about three in the afternoon a large hailstorm fell upon our fields after which our unripe oats were flattened and almost fully threshed out and damaged. The [remaining] yield for the whole village is now tiny [...] and this damage will therefore have a severe effect on the village if tax relief is not granted." (S10) The reports often include a request that the event be investigated and tax relief granted. The Okř́šsy municipality, for example wrote: "Yesterday, 30 May this year [1838], in the afternoon from four to six, a heavy downpour with hailstorm totally destroyed our fields [...]; we therefore request investigation of this damage by a commission and a grant of tax relief." In Prribyslavice, the consequences of the same hailstorm to the crop were such that "[...] sown fields were so flattened that for this year, and perhaps for some years to come, there will be hardly any harvest" (S13). Fears of long-term damage and arable land being rendered unfit for use also appeared frequently in reports made out after torrential rains and flash floods. After such events on 10 May 1833 on the Brtnice estate, the inhabitants of Chlístov and Pokojovice wrote identically that "[fields] have been damaged by water draining off [so badly] that they will remain useless for a long time" and that "[...] many pieces of land have been deprived of necessary soil due to the vehemence of the waters, have become completely infertile [and will remain so] for many years, [...]" (S9).

The report included lists of the land-users who had suffered, together with the areal extent of damage; financial estimates were added in the $19^{\text {th }}$ century. After a hailstorm on 12 August 1820, the following list was compiled: "Owner: Karl Mapa, current tenant: Franz Turek [half-share cultivator]. His rye crop damaged [to the extent of] 10 měřice [1.92 ha] at 4 grains per měřice, [which] amounts to 40 měrice [24.60 hl] at 4 gulden [which] totals 160 gulden; 22 měrice [4.22 ha] of oats at 5 grains, [which] amounts to 110 měřice [67.64 hl], at 2 gulden calculated at 220 gulden; 2 měrice [0.38 ha] of barley at 6 grains amounts to 12 měrice [7.38 hl], counted at 2 gulden 15 kreutzer, [which] amounts to 27 gulden; 2 1/3 měrice [0.44 ha] of spring wheat at 4 grains totals 10 měrice [6.15 hl] at 4 gulden, [which] makes 40 gulden [...]." (S16)

Such lists served as guides for damage commissions and were the basis of damage records. Their form and contents changed over the period studied. In the first half of the $18^{\text {th }}$ century they contained the date of the event, the municipality in question, the names of the peasants involved, the extent of damage in měrice and achtel and the type of damage (largely flooding, clogged and/or flattened crops). They took the form of a handwritten letter. In the second half of the $18^{\text {th }}$ century the records began to include, as well as the name of the claimant, his social status (owner/tenant of the land by acreage - láník [full cultivation rights], puilláník [half-share], čtvrtláník [quarter-share] and so on, as well as the cadastral reference number of the plot and the nature of the land damaged (e.g. sown, arable, fallow, meadow). Later, a description of the plot location was included as well as the type of crop damaged, the extent of damage - one-third (threshold), two-thirds, or total - and the amount of tax relief. Precisely set requirements for the contents of the record only appeared 
after 1819, with printed forms to serve as examples appearing only in 1835 . One such damage record from the Osová estate may serve to illustrate this: "The lands in this village [Víckov] were affected by hailstorm and flood on 27 July 1824." There follows a table, filled out thus: "[serial number] 1 - [surname] Crha Wenzel - [house number] 1 - [toponymic number] 1 - [nature of land] field [land area] 4 jitro $1102 / 6$ square fathoms [2.34 ha] - [annual financial yield] 21 gulden $452 / 4$ kreutzer - [obligatory payment for 1824 - homestead tax] 2 gulden 42 kreutzer [allowance] 54 kreutzer [in total] 3 gulden 36 kreutzer [damage done] half-[relief - homestead tax] 1 gulden 21 kreutzer - [allowance] 27 kreutzer, [in total] 1 gulden 48 kreutzer; [...]." (S24) This kind of application was subject to revision by the damage commission.

A whole range of official correspondence consists of letters from estate officials informing regional officials of the occurrence of an extreme event. On 6 August 1817 an official from Brtnice wrote to the regional office in Jihlava: "On the evening of the first day of this month [1 August] this region was struck by a hailstorm and downpour upon the villages of Uhrínovice, Př́seka, Komárovice, Stř́žzov and Prímélkov which led to considerable damage both to crops and fallow lands as well as to meadows. The honourable I. R. Regional Office is therefore requested to convene an investigation committee into the damage [caused] by hailstorm and water, thus setting in process provision of tax relief for the land in these villages." (S4) The regional office also generated a large body of correspondence, consisting of answers to estate officials, reminders to individual municipalities, complaints from reeves about the practice of a commission, or claims for a new investigation. However, the most frequent source is the appointment of commissioners and establishment of detailed instructions for an investigation. A hailstorm on the Třebíč estate on 1845 provides an example: "[...] the estate municipality of Sokoli on the night of the $5^{\text {th }} / 6^{\text {th }}$ of this month [5/6 August] suffered damage to field crops from hailstorm and it requests an investigation to receive lawful tax relief. This investigation shall be carried out on the spot by Regional Secretary Karl Bretschneider on the $21^{\text {st }}$ of this month [21 August] in the presence of tax collectors from the estate of Budišov and the town of Třebič as assisting commissioners." (S36)

The final - highly important - document in the process of providing tax relief was the actual decision to grant or decline tax relief, from the Moravian Land Administration in Brno. For example, the decision of the Gubernium of 13 November 1834, with reference to a hailstorm on the Velké Meziřričí estate reads: "On 11 August of last year [1833] in consequence of a hailstorm disaster, the municipalities of Horní Radslavice, Mostiště and Martinice are entitled to obtain, in accord with the authority of government decree number 13340 declared on 26 April of this year [1834], tax relief in the amount of 166 gulden $54 / 8$ kreutzer of standard currency for dominical land and 239 gulden 26 kreutzer for rustic land. Total entitlement 405 gulden $314 / 8$ kreutzer of standard currency." (S37)

The period of tax relief was related to the seriousness of the natural disaster and could extend to a number of years. For a hailstorm in the municipality of Benetice on the night of 21/22 May 1839, the Gubernium declared that "[...] land tax relief including the allowance for the year 1839, 11 gulden 2 kreutzer [and] 11 gulden 2 kreutzer for the year 1840 is granted to the owners of rustic land." (S34) 
In the event of extensive damage to crops and a lack of seed-corn, the affected farmers were entitled to request a loan of grain from a "contribution fund". A decree issued on 28 February 1821 notes: "In the spring of 1820 the village of Skřinár̆ov was allowed [...] contribution grain of 8 měrice 5 achtel 2 máz [5.33 hl] of rye and 198 měrice 7 achtel 3 máz [122.32 hl] of oats for a period of two years." (S6) However, a hailstorm on the night of 12/13 August 1820 did such great additional damage that "this borrowed grain will definitely be most necessary this year [and] even more will have to be borrowed and financed". In the end, still greater hardship forced the dependents to write a request in which they "[...] request the 'Honourable Regional Office' [...] to exempt them from the return of 8 měrice 6 achtel 2 máz [5.33 hl] of rye and 198 měrice 7 achtel 3 máz [122.32 hl] of oats, so that the debt would be waived" (S6). One noteworthy example is a document detailing the total amount of grain sent by 24 municipalities from four estates as aid to the Kamenička municipality, devastated by torrential rain with hailstorm and flash flooding on 4 July 1826. Neither tax relief nor contribution grain loan had been enough to cover the damage. A report of 16 September 1826 survives, according to which "the municipality of Černič sends a modest [...] 11 míra and 4 mejtník [about $6.92 \mathrm{hl}$ ] of rye for the inhabitants of Kameničky through local neighbours Mataus Pospissil and Jan Masstera [...]" (S32).

The documents regarding hydrometeorological extremes in the study area are held in the Moravian Land Archives in Brno and in the State District Archives in the towns of Jihlava and Žd'ár nad Sázavou. The archives are arranged in 11 groups, including collections of documents archived adjacent to the estates studied (municipal homesteads Jihlava and Telč, Ždár nad Sázavou estate). All the resources are written in neo-Gothic italic script, largely in German and partly in Czech (especially the damage reports for the latter).

A basis for the study of the impacts of hydrometeorological extremes has been the creation of a database of natural disasters in the study area. It contains a total of 243 records describing 133 extreme events. Hydrometeorological extremes are divided into different types of extreme, such as torrential rain, hailstorm, flash flood, flood, lightning strike (starting fires), drought and frost. It is worth noting that several types of extreme may occur in the course of a single event. The frequency of extremes is then expressed both by individual event and type of extreme.

\title{
4. Results
}

\author{
4.1. Hydrometeorological extremes, \\ communities affected, and tax relief
}

As taxation records only capture the events that led to the kind of damage justifying a request for tax relief, the overall frequency of these events expresses the exposure of a given area to hydrometeorological extremes. In the given area, 133 cases of this kind occurred between 1706 and 1889 (Fig. 3a), in 70 individual years during that period. The maximum was recorded in 1830 with six hydrometeorological extremes, with five in 1826 and four in 1792, 1827, 1837, 

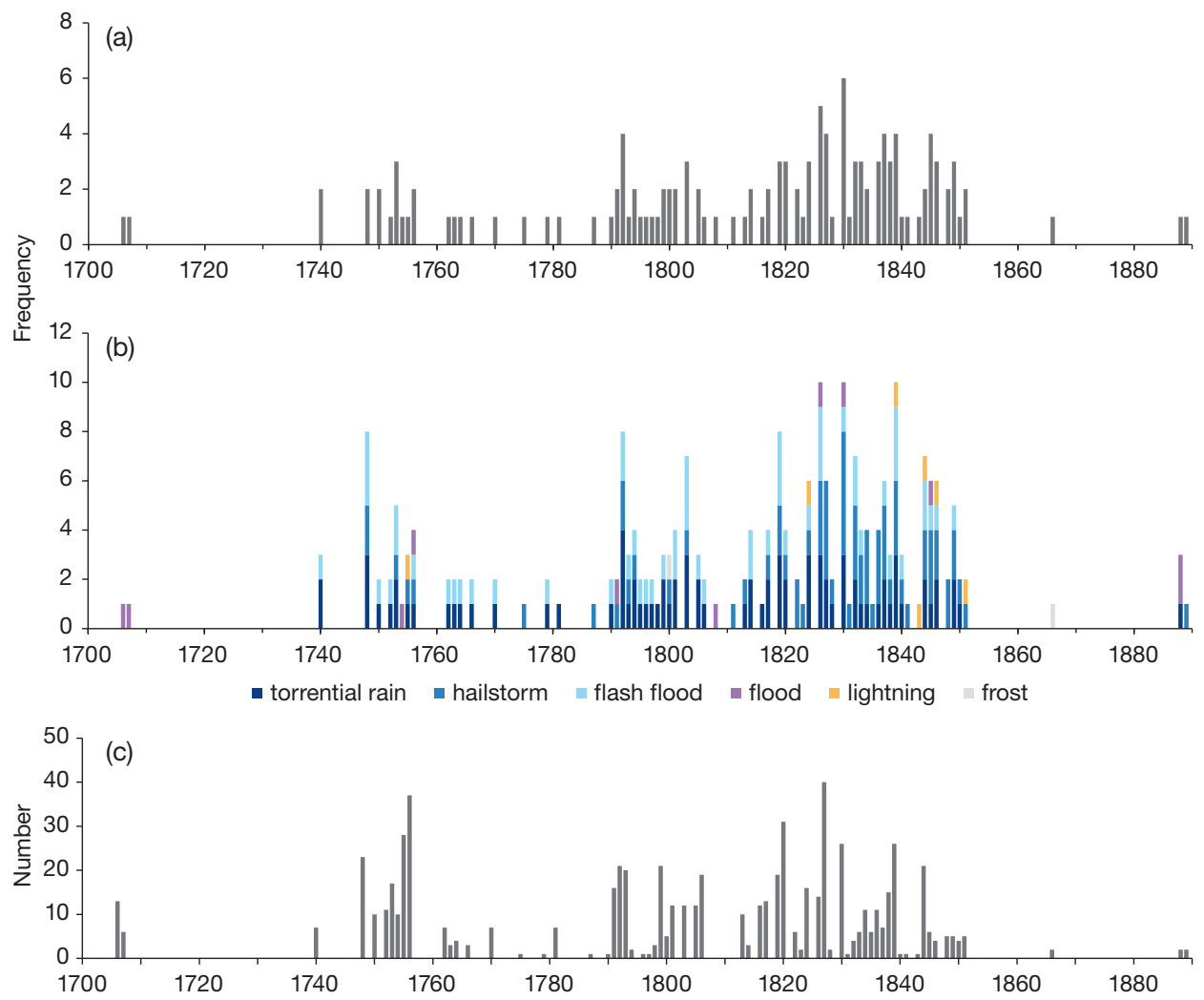

Fig. 3 - Frequency of hydrometeorological extremes at seven estates in the Bohemian-Moravian Highlands in 1706-1889: (a) total, (b) hydrometeorological extreme type, (c) number of communities affected

1839 and 1845 . In categorical terms (Fig. $3 \mathrm{~b}$ ), they were largely torrential rain (85 cases), hailstorms (73), flash floods (57), floods (11), lightning strikes starting fires (7) and late frosts (2). The highest frequency of events was recorded between 1821 and 1850. The total extent of the occurrence of damage may be deduced from the number of municipalities affected (Fig. 3c). Some of these places may be included more than once in the list of events for individual years if they were affected more than once in the given year. The maximum number of municipalities involved occurred in 1827 (40), followed by 1756 (37), 1820 (31) and 1755 (28). The majority were situated in the villages of the Brtnice estate: Číchov (19 times), Bransouze and Petrovice (18) and Dolní Smrčné (17). In 1827 the municipalities of Kožichovice and Pozd'átky on the Třebíč estate were affected three times: on 9 June, 18 June and 10 August (together with a further occurrence of damage elsewhere on 19 August, this estate was affected four times in total). Three extremes were recorded in the settlements of the Velké Meziříčí estate in 1830.

However, it is not easy to obtain a more exhaustive idea of the extent of tax relief granted from damage records because a certain amount of information 
is either missing or fragmentary. The only exception is tax relief in response to hailstorm damage in the 1822-1846 period acquired for five of the estates studied (Fig. 4). The worst year was 1844, with 25 municipalities granted a total of tax relief amounting to 5302 gulden (the following examples serve to place monetary units in context, in terms of mid- $19^{\text {th }}$ century daily salaries: qualified workers on the building the Olomouc-Prague railway track 1 gulden 30 kreutzer to 2 gulden; textile factory worker 1 gulden 23 kreutzer; domain administrator 1 gulden 18 kreutzer, miner 1 gulden 12 kreutzer to 1 gulden 18 kreutzer; draper 1 gulden; tailor 40 kreutzer - Machačová, Matějček 2010). This arose out of an event on 25 June in which a thunderstorm with heavy hail and torrential rain moved from south-west to north-east in the course of the evening and destroyed all or three-quarters of the field crops and hay in the meadows. The damage was reported by at least 81 peasants and the hailstorm affected at least 1180 ha of fields in a total of 36 municipalities on the six estates. Tax relief ranged between $50 \%$ and $100 \%$. In Ruda a shepherd's shed was struck by lightning and 120 shocks of hay burnt (S18, S26, S29, S35, S38). Based on taxation data, this was territorially the second most extensive damaging hailstorm in South Moravia: harm was documented for 67 communities on
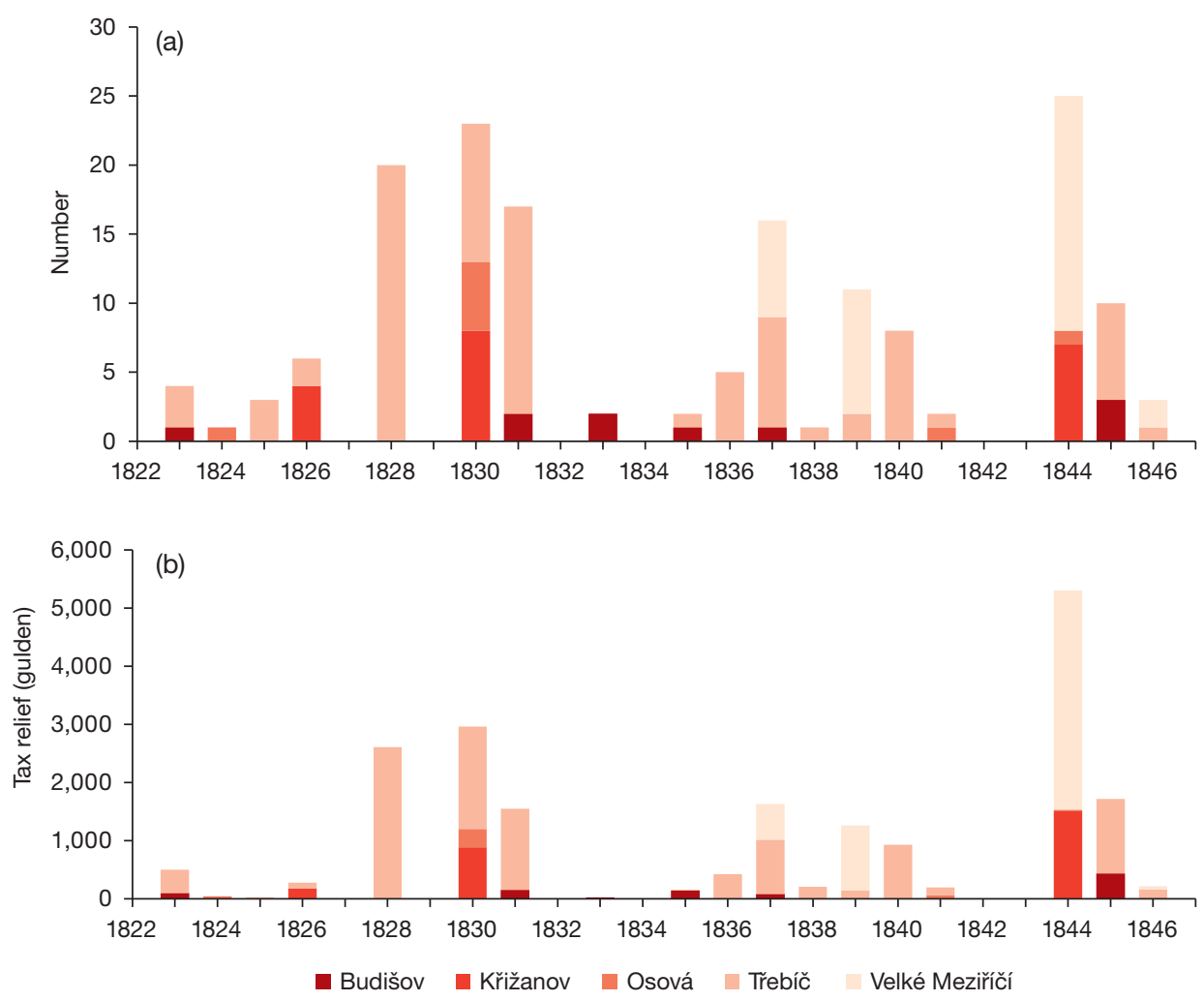

Fig. 4 - Number of communities affected by hailstorm (a) and granted tax relief (b) for the Budišov, Křižanov, Osová, Třebíč and Velké Meziřičći estates in the 1822-1846 period (S20) 
16 estates (Brázdil et al. 2014b). Figure 4 further shows that a higher number of affected communities corresponds to higher tax relief. On the other hand, no tax relief at all was granted to three communities affected in 1825 and two in 1833.

\subsection{Impacts of hydrometeorological extremes}

No loss of human life associated with hydrometeorological extremes was reported in the damage records analysed for the area studied. What follows concentrates on the impacts of hydrometeorological extremes on agriculture and crop cultivation, on material property, and on social-economic impacts.

\subsubsection{Impacts on agriculture and crop production}

This group of impacts may be further divided:

1. Impacts on fields and crops: In general, field crops tended to be damaged by hailstorms, often in association with torrential rain and flash floods. The most widely-grown cereals (rye, oats, barley, spring wheat) frequently suffered most, but peas and lentils were not exempt, as was the case in Ořechov on the night of 12/13 August 1820 (S16). Hailstorms also damaged fruit trees or knocked fruit down in orchards and gardens; the strong winds that accompanied them broke tree branches. Damage records usually detailed the extent of damage as one-third, half, two-thirds, or total. Subsequent flash-flooding of an already damaged crop was not uncommon, as in five settlements on the Brtnice estate on 25 July 1819 (S5). Torrential rain with hailstorm and flash flood to follow on 25 July 1826 on the Třebíč estate constituted an emergency: field crops in Kamenička were damaged in such a way that local inhabitants brought in no harvest at all and in Kamenice "[...] in many places so much hail lay on the ground that it did not melt or disappear for three days [...]" (S6). The extent of damaged and flattened rye alone in this case was estimated at over 57.6 ha.

Fields were under water after torrential rains and floods. Although most damage compensation pertained to sown fields, tax relief was also granted for flooded fallow ground. If the water remained in the fields for any length of time, the crops died off and they had to be ploughed under. The fields were thus rendered unusable for that year. This occurred in Krahulov on 27 June 1830. A flash flood covered parts of the fields in sand, gravel and stone sediments, leading to loss of the arable potential and a low harvest, or none at all. Then material deposited had to be removed in order to open up the land for further sowing. In other fields, torrents of water led to erosion, wearing away drainage ditches and washing away soil. Such a loss of topsoil could be total, including any crops growing in it, or partial, in which case the roots of plants were uncovered and they died off. A report on the consequences of torrential rains on 14 and 17 September 1806 in 20 municipalities on the Brtnice estate records that: "[...] the villages suffered [...] no small damage to their fields and meadows and in both ploughed and sown fields the cultivated 
soil was washed away [...], then the partially uncovered base was carried away and also clogged with mud in places [...]." (S3)

Crops were also endangered by drought and late frosts. However, these were not considered bureaucratically significant hydrometeorological extremes and no tax relief was available for them.

2. Impacts on meadows and pastures: Meadows and pastures situated near watercourses were prone to flooding. Grass was fouled with sand, gravel, mud and stones, hay was destroyed and haystacks carried away. If floods occurred later in the year, the aftermath suffered, as in Markvartice in 1748 (S1). While in some meadows water ran off and left only sediments, in others it formed long-lasting lagoons. Damage to meadows is always classified as total in official records and full tax relief was granted.

It was occasionally impossible for several years afterwards to use pastures or meadows that had been flooded or clogged (see torrential rain and flash flood in Červená Lhota on 29 May 1826 with estimated damage of 80 gulden 22 kreutzer; S31). Problems with pastures and meagre harvests led to lack of fodder in winter. Both resulted in reductions in the number of cattle, in turn reducing the amount of manure required as fertiliser. Reduction of the number of cows was especially severe, largely because of decreases in milk production. Major floods could also lead to the reshaping of meadows and pastures in their vicinity. Thus, as a result of torrential rain on 3 May 1820, the water level of the River Jihlava rose in Číchov and in addition to flooding fields, demolishing houses, damaging mills and drowning cattle, it also swept away its own banks and changed the contours and outlines of many meadows (S6).

3. Impacts on livestock: Loss of livestock was a serious consequence of hydrometeorological extremes. The flood of the River Jihlava at Ćíchov mentioned above (S6) is an example. Livestock was also vulnerable to fire. On 7 June 1846, there was a fire on Hynkov Farm after a lightning strike. All the animals were taken out of doors in time, but the granary and all of the farm's straw burned away (S14). Matters were even worse if fire broke out after the harvest. After a lightning strike on 6 September 1824 in Kněžice, all of the harvest stored in a barn was lost to fire (S7). Cattle also starved as a result of flooded and clogged pastures and meadows in which the hay had been destroyed.

\subsubsection{Impacts on material property}

Almost all hydrometeorological extremes did damage to property. In most cases, floods rose into houses, farm buildings, yards, gardens, meadows and fields. Water undermined houses, roads and bridges, carried away movable property (farm tools, domestic equipment), haystacks and wood-piles, as well as tearing down fences, damaging roads and square pavements, destroying riverbanks and altering the contours of floodplains. They posed a great threat to watermills, putting them out of service and possibly doing mechanical damage. However, over time, millers learned to be prepared for annual floods and managed to protect the mills against damage to some extent (Votruba, Patera 
2004). Damage to a mill usually indicates events of particular severity. For example, a flood in Víckov on the River Bobrůvka in 1888 clogged the millrace and destroyed the water gate (S28). Bridges could be demolished intentionally during a flood if they were instrumental in obstructing flow. During a flood on the River Oslava on 18 March 1830, the inhabitants of Velké Meziř́čí were forced to tear down the bridge in Dolní Město where ice floes had accumulated and made the Oslava overflow, flood the town, and find relief only through a street that led to the River Balinka (Hodeček et al. 2008). Fish cultivation ponds and lakes, often bodies of water of great size, also presented a potential threat: if their retaining walls failed, there was always the risk of another, quite substantial, flood wave.

Damage to material property was also done by hailstones, which often broke windows or damaged roofs. The consequences of this were especially tragic if such ventilation enabled a fire to spread on the wind to other buildings. On 5 August 1839, a lightning strike set fire to residential and farm buildings belonging to three people in Osová Bítýška. In addition to the buildings, the fire destroyed equipment, wood supplies, food, clothes and stored crops. The damage was estimated at 860 gulden, so the relief of annual land tax set by the government at 21 gulden 36 kreutzer was small consolation (S25). On 24 June 1755, a fire was started by a ball lightning in Brtnice: "[...] the first stroke of lighting hit the tip of the monastery church steeple above the main altar and it smashed a beam [that stood there] into tiny pieces; it tore off roof slates and then proceeded under the vault, in which it punched three large holes, and it [also] made two cracks behind the blazon of a noble count." It cracked in the walls and broke several windows as well (S2).

\subsubsection{Socio-economic impacts}

The impacts of hydrometeorological extremes on agriculture and its production, as well as direct material damage, led to significant socio-economic problems. Partial or total loss of harvest meant a lack of seeds to sow in the following year. A loan from the contribution fund established by Joseph II in 1782 could make up for this. However, like any loan, it had to be paid back, in this case within a year and including interest (Vondruška 1989). As contribution loans were only made in response to extreme events, it is possible to determine especially significant disasters by examining contribution fund records. Loss of harvest also led to decreases in financial income that might otherwise have resulted from the sale of grain; this found a reflection in the inability of hydrometeorological extreme victims pay back the grain loan. Requests for complete repayment exemption were rejected but, for example, farmers from Skřivanov affected by a hailstorm on 12-13 August 1820 were allowed two years grace and the interest was waived (S23). In addition to all this, those who worked the land were often forced to take financial loans for more seeds and routine daily consumption; the repayment period extended to several years and the outstanding debt was, of course, subject to further interest. This drove people off the land and rendered many unable to pay taxes and to meet other social financial obligations. Decreased household income 
led to lower investment in farming, both as it stood and in any potentially progressive development.

The impacts of an extreme event were compounded if hydrometeorological extremes hit a single area several times within a short time period (for example, downpours and flash floods on 22 and 25 May 1820 on the Brtnice estate [S6]), the same villages several times in one year (torrential rains and hailstorms in Kožichovice and Pozd’átky in 1827 - see Sect. 4.1 [S8, S33]) or for several consecutive years (Přibyslavice in the 1836-1838 period [S11] and Okř́šsky between 1837 and 1839 [S12]). In these extreme situations, the level of damage was so high that relief of annual land tax was nowhere near sufficient to cover costs, although it could be extended for up to four years. In especially serious cases, when even a loan from the contribution fund proved inadequate, a public collection was proclaimed. For example, for the Kamenička municipality, stricken by torrential rain, flash flood and hailstorm on 4 July 1826, a collection carried out in neighbouring municipalities gathered $70.5 \mathrm{hl}$ of rye (S31). The long-term result of repeated extremes was eventually a decrease in cereal production, lack of finance, limitation of expenditure and impoverishment of all those who worked the land.

While every effort was made to alleviate the consequences of hydrometeorological extremes, there remained little time and energy for other economic activities. Snowstorms, too, had similar consequences to those of "listed" hydrometeorological extremes, leading to impassable streets and roads and therefore limitation of communication both in the town and its immediate environment. Such cases were recorded for the Moravské Budějovice estate in 1829, 1835 and 1837; however, they were also closely linked to the study area (S15).

\section{Discussion}

A certain limiting factor in the use of taxation records is that after tax relief had been granted or declined, the related documents became outdated and it was up to the officials involved, administrators and estate owners, whether to archive the documentation or discard it. This makes for a certain temporal and spatial heterogeneity of surviving records in terms of their completeness. For example, for this study, no taxation data were available for 1708-1739, $1852-1865$ and $1866-1887$. This presents a significantly less serious problem in the study of the effects of hydrometeorological extremes than in the analysis of the frequency and severity of individual hydrometeorological extremes. On the other hand, the absence of records of a certain hydrometeorological extreme at a given estate is often filled in the collection of a neighbouring estate that sent a commissioner to evaluate the damage reported. Further, the level of damage to crops shifted in response to vegetation period and current phenophase (flowering, ripening etc.) and associated variations in sensitivity to the influence of the weather. For example, rye was at its most vulnerable during flowering, wheat during ear formation and oats during the ripening period (Fassbender 1898). Thus, not every extreme achieved the minimum of one-third damage to field crops required to apply for tax relief and therefore did not appear in taxation records. 


\subsection{Alleviation of the negative impacts}

of hydrometeorologicl extremes

Victims of hydrometeorological extremes suffered in many ways, not least in the loss of homes to fire or flood or burnt-down farm buildings, loss of equipment, harvest devastated in the fields and granaries and livestock drowned or starved. Without quite substantial aid, any or all of these led to poverty and distress.

Such victims of circumstances were largely granted relief from land tax (Grundsteuer) and from surtax (Zuschuss), or they were totally exempted, depending on how serious the damage was. A completely destroyed field yield corresponded to relief from annual land tax and surtax, yield damaged by half equated to six months' relief of both taxes and by a third qualified for a year's exemption from surtax. However, such rebate could only be granted once in a year and only if relief from the previous year was not in force. The level of tax relief was also influenced by the time during which pastures were not in use (S22). When the Maria Theresa Land Registry was in force, land tax was set at $33 \%$ of gross yield and later in the course of the study period it ranged between $12 \%$ and $21 \%$ of net annual yield from a given plot (Kocman et al. 1954). In the 1840 s, an average farmer was liable for $27 \%$ of the annual yield of his farm to his landowner; he paid, in tax and or in kind, $18 \%$ to the crown, $6 \%$ to the church and $5 \%$ to the village, while servicing a debt of $14 \%$. All of this meant that only $30 \%$ of the annual yield remained to the farmer (Machačová, Matějček 2010). If a house was damaged, relief of housing tax could be granted. In spite of all this, even $100 \%$ tax relief could not compensate for the loss of an entire harvest or a homestead destroyed by fire. Further, tax relief was declined in some cases (for example if the investigating commission found an insufficient level of damage).

Public requests for funds were proclaimed in order to assist afflicted municipalities, while neighbouring civic entities and estates voluntarily contributed supplies of grain. Such collections were largely intended for the victims of fires rather than hydrometeorological extremes, since fires were generally considered to be the more damaging. The collection of financial resources as aid could be declared for particular hardship on distant estates (e.g. Potštát) or lands (Tyrol, Baden-Württemberg). As well as financial aid, grain supplies were sent if damage to cereals was acute and both tax relief and contribution fund loans proved insufficient (e.g. in response to a hailstorm on 4 July 1826 in Kamenička). A swift rectification of conditions was in the best interests of the nobility; sometimes they even provided direct aid. For example, after a calamitous flood in Číchov on 23 May 1820, approval to send auxiliary workers to help with the repair of damaged riverbanks on the River Jihlava, and with removing sediments, was granted in addition to tax relief. Removing snow after snowstorms made some money for the people taking part in the work; such labourers often came from neighbouring estates. One positive aspect of the different times at which cereals ripen was that farmers could, in the event of damage to earlier-ripening crops (spring barley, winter wheat), turn to cereals yet to mature, such as oats; this was the case on the Křžanov estate in 1820 (S16). 


\subsection{Problems associated with the support of those affected by hydrometeorological extremes}

The situation of those deprived or impoverished by hydrometeorological extremes was often complicated by delays in damage investigation and the routine exigencies of bureaucracy. Blame for this lay on both sides: estate officials and tax collectors and peasants alike were often slow to react for a variety of reasons. These delays took a toll upon the time required to process tax relief and other requests (fund loans, etc.), indirectly influencing the lives of those afflicted and exacerbating already poor living conditions.

The list of estate dependents that should have been compiled by an estate official was often missing from an application (involving a delay of up to 20 days). Sometimes the damage report was sent late - up to five days (priority being given to salvaging a maximum of crops and reduction of damage in the request for tax relief). Mistakes crept into damage records (imprecise calculations) and it took time to make essential corrections. The sheer weight of a severe hydrometeorological extreme, with a high number of villages affected, could also slow down work at estate offices. For example, on 24 June 1755, hailstorm damage was reported by 28 villages on the Brtnice estate (S2). Widespread damage and the associated need for several days of investigation (three days) or a delay at governmental level (up to five months) could also influence matters. Transport had to be organised - a horse or even a horse and cart - in order to ensure the timely arrival of a damage commission at distant localities in the mountains (for example, for the municipalities on the Velké Meziř́čí estate affected by hailstorms before 30 June 1839 [S17]). Delays also arose out of particularly detailed investigation if there was a suspicion of intentional exaggeration of damage (e.g. a fire caused by lightning strike in Milešín on 15 August 1851 [S27]).

In some cases, the applicants were dissatisfied with the decision of the provincial government and petitioned for reinvestigation and more tax relief. For example, after a revision regarding torrential rain, flash flood and hailstorm in Nárameč on 27 May 1830, the damage level was increased to the minimum threshold of a third and the total extent of fields acknowledged as affected was widened (S21).

\subsection{Accumulation of impacts}

The complexity of relations between the physical and the human world complicates the study of climate impacts and hydrometeorological extremes. A number of different models may be employed to address this (Kates 1985; Pfister 2005, 2007). The basic model of climate impacts on society includes a sequence of cascading impacts, the root cause of which is the occurrence of climatic extremes or hydrometeorological extremes (Kates 1985, Pfister, Brázdil 2006):

1. Biophysical impacts take the form of lower yields and reduced nutritional potential in terms of the production of food (yields per hectare, relation of 


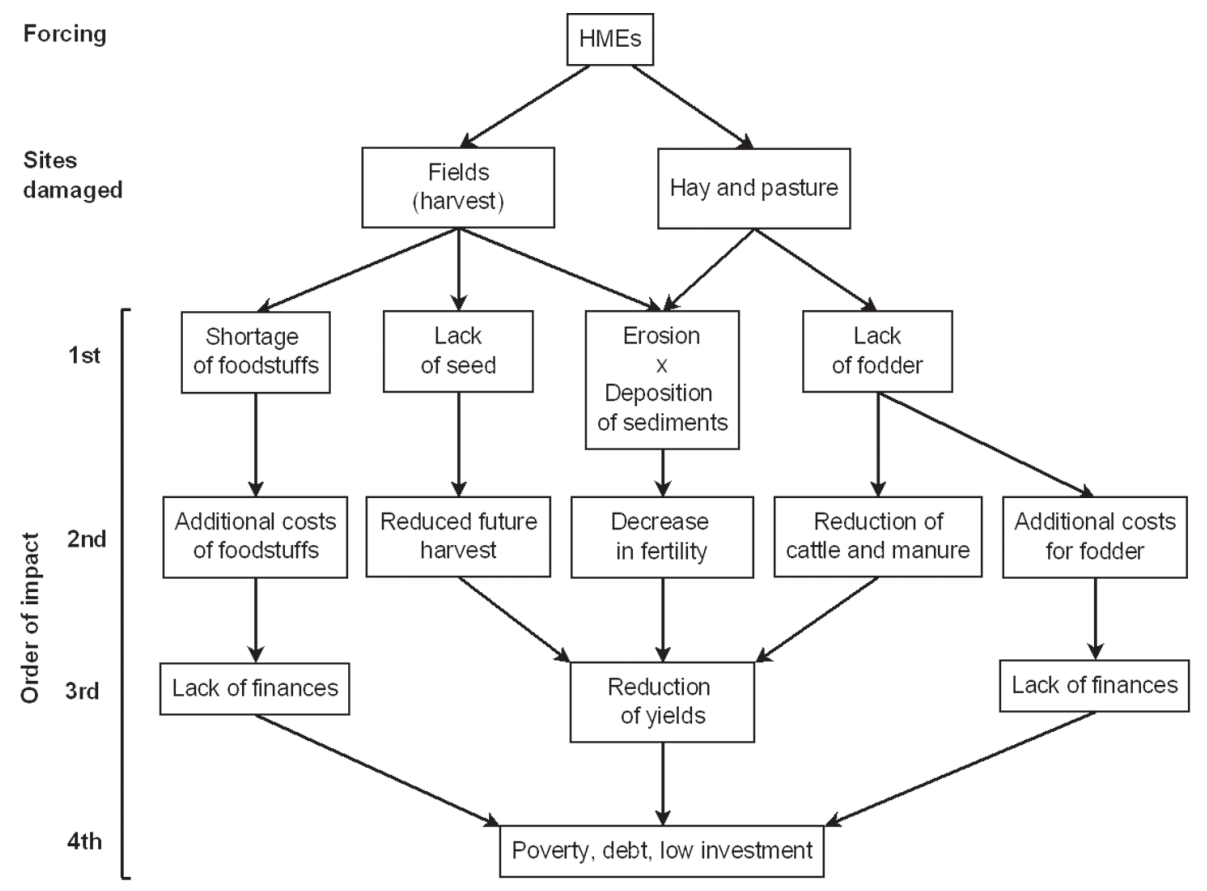

Fig. 5 - A model of hydrometeorological extremes impacts on fields and meadows in the area studied

seeded to harvested grains) and its availability (also considering losses in storage).

2. Economic matters impact mainly upon the prices of food (grain prices were particularly important; prices rise sharply with scarcity), animal feed and firewood.

3. Demographic and social impacts are expressed as malnutrition, decline in birth-rate, rises in death-rate, social disruption and starvation-forced migration (subsistence crises).

The study of impacts at local and sub-regional level enables the creation of a model of hydrometeorological extreme impacts (Fig. 5) with reference to biophysical and economic factors, on damage done to fields and meadows. Possibly the most serious problem was the loss of a grain harvest, bearing in mind that, in the $18^{\text {th }}$ and the $19^{\text {th }}$ century, mean grain yield was only three times the quantity sown (Kubačák 1994). For example, only three times as much rye, and two times the quantity of cereals sown was harvested on the Brtnice estate in 1781-1782 (Ježková 1963). The impacts of grain loss may be divided into four levels. Lack of grain and seeds for further sowing characterises the first. In turn, a lack of cereals had to be made up for by purchase of food from beyond the farmstead, which led to unplanned expenditure, reflected in deterioration in the farmers' finances. Damage to cereals meant less seed grain and therefore reductions in area sown; future harvests were lower and total yields reduced. 
Thus crop failure reduced income from the sale of grain and complicated further sowing. Reduction of yield could also result from physical damage to fields (clogging with introduced material, erosion, ablation of ploughing layer). Flooding or clogging also resulted in a lack of fodder and pasture for cattle, again with a cascade of consequences. One possible solution to this problem was to keep fewer cattle, resulting in lower milk production and reduction of the quantity of manure for fertiliser. Farmers caught in such situations attempted to replace losses by intensifying production on undamaged plots. Another possibility was to buy feedstuff for the cattle. This, however, led to additional financial burdens. In all these ways, financial resources were drained (the use of loans, paying back interest, debt), and farmers' poverty intensified while investment in the farmstead was reduced or curtailed.

\section{Conclusions}

This contribution provides a new perspective on the use of information about hydrometeorological extremes derived from taxation records (Brázdil et al. 2012, 2014a, 2014b; Dolák, Brázdil, Valášek 2013), contributing a more extended view of their human impacts. The example employed consists of seven estates in the Bohemian-Moravian Highlands between 1706 and 1889. The records show that the most frequent direct impacts of hydrometeorological extremes on the extent and quality of agricultural production were also exacerbated by significant material damage that resulted in deterioration in the socio-economic position of farmers and their families in both the short term and the long. Direct impacts included the loss of property, stock, equipment and livestock, crop failure and/or damage to cultivated lands. While the affluent classes were able to overcome these losses quite easily, their subjects suffered from serious long-term consequences such as lack of capital, debt, poverty, and forced reduction of livestock as well as diminishing field fertility.

The analysis herein also identifies a range of vulnerability to hydrometeorological extremes in the study area. Leaving aside the fact that the lands cultivated by subjects were usually situated in more marginal and endangered areas (such as floodplains) than the lands of the aristocracy, important differences may also be found in more concrete terms. In the western part of the territory (the Brtnice estate), with its deeply-cut river valleys (River Brtnice and River Jihlava), the settlements on the slopes were often the victims of floods (including flash floods) and inundations (30.8\% of cases), especially wherever a number of streams met. In contrast, in the eastern part of the territory (the Křižanov and Osová estates and part of the Velké Meziř́ičí estate), with their wide valleys and smaller differences in elevation, the proportion of floods was significantly lower (10\%) and much of the reported damage was due to hailstorms (57\%).

In spite of existing uncertainties in the use of taxation records (Brázdil et al. 2012, Dolák, Brázdil, Valášek 2013), especially in their spatio-temporal coverage, this study makes a contribution to knowledge of the human impacts of hydrometeorological extremes in the $18^{\text {th }}$ and $19^{\text {th }}$ centuries at local and subregional levels. Methodologically, it also serves as a basis for similar studies 
covering all of southern Moravia. The basic excerption of accessible taxation records from all the estate farms has already been carried out (see Brázdil et al. 2014a, 2014b).

We would like to thank Ladislav Čech (Prostějov) for initial translation of the article and Tony Long (Svinošice) for final editing of the English.

\section{References:}

BRÁZDIL, R., CHROMÁ, K., ŘEZNÍČKOVÁ, L., VALÁŠEK, H., DOLÁK, L., STACHOŇ, Z., SOUKALOVÁ, E., DOBROVOLNÝ, P. (2014a): The use of taxation records in assessing historical floods in South Moravia, Czech Republic. Hydrology and Earth System Sciences, 18 , No. 10 , pp. $3873-3889$.

BRÁZDIL, R., CHROMÁ, K., VALÁŠEK, H., DOLÁK, L. (2012): Hydrometeorological extremes derived from taxation records for south-eastern Moravia, Czech Republic, 1751-1900 AD. Climate of the Past, 8, No. 2, pp. 467-481.

BRÁZDIL, R., CHROMÁ, K., VALÁŠ̌EK, H., DOLÁK, L., ŘEZNÍČKOVÁ, L. (2014b): Damaging hailstorms in South Moravia, Czech Republic, in the $17^{\text {th }}-20^{\text {th }}$ centuries derived from taxation records. Theoretical and Applied Climatology, http://ink.springer.com/article/1 0.1007\%2Fs00704-014-1338-1 (21.5.2015).

BRÁZDIL, R., DOBROVOLNÝ, P., LUTERBACHER, J., MOBERG, A., PFISTER, C., WHEELER, D., ZORITA, E. (2010): European climate of the past 500 years: new challenges for historical climatology. Climatic Change, 101, No. 1-2, pp. 7-40.

BRÁZDIL, R., PFISTER, C., WANNER, H., von STORCH, H., LUTERBACHER, J. (2005): Historical climatology in Europe - the state of the art. Climatic Change, 70, No. 1, pp. 363-430.

BRAZDIL, R., VALÁŠEK, H. (2003): Use of historic data in studying damage due to natural disasters at the domain of Pernštejn in the period 1694-1718 and as a source of information for the study of meteorological and hydrological extremes. Meteorologický časopis, 6 , No. 1 , pp. 3-13.

BRÁZDIL, R., VALÁŠEK, H., CHROMÁ, K. (2006): Documentary evidence of an economic character as a source for the study of meteorological and hydrological extremes and their impacts on human activities. Geografiska Annaler, 88 A, No. 2, pp. 79-86.

BRÁZDIL, R., VALÁŠEEK, H., SVITÁK, Z. (2003): Meteorological and hydrological extremes in the Dietrichstein domains of Dolní Kounice and Mikulov between 1650 and 1849 according to official economic records of natural disasters. Geografický časopis, 55, No. 4, pp. 325-353.

BUDŇÁKOVÁ, M., JACKO, K. (2012): Situační a výhledová zpráva. Půda. Ministerstvo zemědělství, Praha, 102 pp.

CHROMÁ, K. (2011): Nebezpečné hydrometeorologické jevy v písemnostech panství Veselí nad Moravou v období 1784-1849. Meteorologické zprávy, 64, No. 1, pp. 23-29.

CHROMÁ, K., BRÁZDIL, R., VALÁŠEK, H., ZAHRADNÍCEEK, P., DOLÁK, L. (2013): Past hydrometeorological extremes in south-western Moravia (Czech Republic) derived from taxation records. In: Stojanov, R., Žalud, Z., Cudlín, P., Farda, A., Urban, O., Trnka, M. (eds.): Global Change and Resilience. From Impacts to Responses. Proceedings of the $3^{\text {rd }}$ annual Global Change and Resilience Conference. Global Change Research Centre, Academy of Sciences of the Czech Republic, v. v. i., Brno, pp. 110-114.

DOLÁK, L., BRÁZDIL, R., VALÁŠEK, H. (2013): Hydrological and meteorological extremes derived from taxation records: the estates of Brtnice, Třebíč and Velké Meziříćí, 1706-1849. Hydrological Sciences Journal, 58, No. 8, pp. 1620-1634.

FASSBENDER, J. (1898): Taxace krupobitních škod způsobených na hospodářských plodinách se stručným popisem nemocí rostlin, škodlivého hmyzu...: příruční kniha pro taxátory, úředníky a jednatele krupobitních pojištoven. J. Fassbender, Praha, 183 pp. 
GARCÍA, R., MACIAS, A., GALlEGO, D., HERNÁNDEZ, E., GIMENO, L., RIBERA, P. (2003): Reconstruction of the precipitation in the Canary Islands for the period 1595-1836. Bulletin of the American Meteorological Society, 84, No. 8, pp. 1037-1039.

GROVE, J.M., BATTAGEL, A. (1983): Tax records from western Norway, as an index of Little Ice Age environmental and economic deterioration. Climatic Change, 5, No. 3, pp. 265-282.

HAMERNÍKOVÁ, A. (1968): Velkostatek Velké Meziříčí (1448) 1613-1948. Inventář. Státní archiv v Brně, Brno, 118 pp.

HODEČEK, D., JIČÍNSKÝ, P., KRUŽÍK, M., KUBÍČEK, J., MĚŘÍNSKÝ, J., RIPPOROVÁ, M., SALAŠ, M., ŠTINDL, M. (2008): Velké Meziříčí v zrcadle dějin. Muzejní vlastivědná společnost, Brno, 479 pp.

HORÁK, K. (1961): Velkostatek Křižanov (1434) 1641-1945. Inventář. Státní archiv v Brně, Brno, $28 \mathrm{pp}$.

JEŽKOVÁ, M., ŠTARHA, I. (1961): Velkostatek Třebíč (1335) 1538-1949. Inventář. Státní archiv v Brně, Brno, 141 pp.

JEŽKOVÁ, M. (1963): Velkostatek Brtnice (1537) 1562-1947 (1963). Inventář. Státní archiv v Brně, Brno, $61 \mathrm{pp}$.

KATES, R.W. (1985): The interaction of climate and society. In: Kates, R.W., Ausubel, J.H., Berberian, M. (eds.): Climate Impact Assessment. Studies of the Interaction of Climate and Society. John Wiley, Chichester, pp. 3-36.

KISS, A., WILSON, R., BARISKA, I. (2011): An experimental 392-year documentary-based multi-proxy (vine and grain) reconstruction of May-July temperatures for Köszeg, WestHungary. International Journal of Biometeorology, 55, No. 4, pp. 595-611.

KOCMAN, A., MUSILOVÁ, M., PLETKA, V., RADIMSKÝ, J., ŠVẢBENSKÝ, M., TRANTÍREK, M., URBÁNKOVÁ, L., WURMOVÁ, M. (1954): Průvodce po Státním archivu v Brně. Krajské nakladatelství, Brno, 590 pp.

KUBAČÁK, A. (1994): Dějiny zemědělství v Českých zemích I. Od 10. století do roku 1900. Ministerstvo zemědělství ČR, Praha, $191 \mathrm{pp}$.

LEIJONHUFVUD, L., WILSON, R., MOBERG, A. (2008): Documentary data provide evidence of Stockholm average winter to spring temperatures in the eighteenth and nineteenth centuries. The Holocene, 18, No. 2, pp. 333-343.

LUTERBACHER, J., KOENIG, S.J., FRANKE, J., VAN DER SCHRIER, G., ZORITA, E., MOBERG, A., JACOBEIT, J., DELLA-MARTA, P., XOPLAKI, E., WHEELER, D., RUTISHAUSER, T., STOSSEL, M., WANNER, H., BRÁZDIL, R., DOBROVOLNÝ, P., CAMUFFO, D., BERTOLIN, C., VAN ENGELEN, A., GONZÁLEZ-ROUCO, F., WILSON, R., PFISTER, C., LIMANOWKA, D., NORDLI, Ø., LEIJONHUFVUD, L., SOEDERBERG, J., ALLAN, R., BARRIENDOS, M., GLASER, R., RIEMANN, D., HAO, Z., ZEREFOS, C. (2010): Circulation dynamics and its influence on European and Mediterranean January-April climate over the past half millennium: results and insights from instrumental data, documentary evidence and coupled climate models. Climatic Change, 101, No. 1-2, pp. 201-234.

MACHAČOVÁ, J., MATĚJČEK, J. (2010): Nástin sociálního vývoje českých zemí 1781-1914. Praha, Karolinum, 494 pp.

MATUŠÍKOVÁ, L. (1996): Zivelní pohromy na komorních panstvích v Polabí ve druhé polovině 17. století. AUC-Philosophica et historica, $5, \mathrm{Z}$ pomocných věd historických XIV, pp. 137-141.

NOVOTNÝ, J. (1936): Moravský berní systém v století 17. a 18.: příspěvek k hospodářským dějinám země. Státní nakladatelství, Brno, $127 \mathrm{pp}$.

NOVOTNÝ, J. (1959): Poddanská půda na Moravě v 16. a 17. stol., příspěvek k poznání výrobního prostředku zemědělského lidu v době feudalismu. In: Sborník archivních prací 1. Archivní správa ministerstva vnitra, Orbis, Praha, pp. 162-237.

OBRŠLÍK, J., REZNÍČEK, J., VOLDÁN, V. (1966): Průvodce po archivních fondech, Státní archiv Brno. Archivní správa ministerstva vnitra, Praha, 476 pp.

PFISTER, C. (2001): Klimawandel in der Geschichte Europas. Zur Entwicklung und zum Potenzial der historischen Klimatologie. Österreichische Zeitschrift für Geschichtswissenschaften, 12 , No. 2, pp. 7-43.

PFISTER, C. (2005): Weeping in the snow. The second period of Little Ice Age-type impacts, 1570-1630. In: Behringer, W., Lehmann, H., Pfister, C. (eds.): Kulturelle Konsequenzen 
der "Kleine Eiszeit" - Cultural Consequences of the "Little Ice Age". Vandenhoeck \& Ruprecht, Göttingen, pp. 31-86.

PFISTER, C. (2007): Climatic extremes, recurrent crises and witch hunts: Strategies of European societies in coping with exogenous shocks in the late sixteenth and early seventeenth centuries. The Medieval History Journal, 10, No. 1-2, pp. 33-73.

PFISTER, C. (2010): The vulnerability of past societies to climatic variation: a new focus for historical climatology in the twenty-first century? Climatic Change, 100, No. 1, pp. 25-31.

PFISTER, C., BRÁZDIL, R. (2006): Social vulnerability to climate in the "Little Ice Age": an example from Central Europe in the early 1770s. Climate of the Past, 2, No. 2, pp. 115-129.

PFISTER, C., LUTERBACHER, J., WANNER, H., WHEELER, D., BRÁZDIL, R., GE, Q., HAO, Z., MOBERG, A., GRAB, S., DEL PRIETO, M. R. (2008): Documentary evidence as climate proxies. In: PAGES (Past Global Changes), Proxy-specific White Paper produced from the PAGES/CLIVAR workshop, Trieste, $10 \mathrm{pp}$.

ŠIMEK, A. (1918): Z minulosti pozemkového katastru země Moravskoslezské. Státní nakladatelství, Brno, $70 \mathrm{pp}$.

VOLDÁN, V., HORÁK, K., JEŽKOVÁ, M., KUDRNOVÁ, D., KYASOVÁ, V., OBRŠLÍK, J., ŘEZNÍČEK, J., ZŘÍDKAVESELÝ, F. (1964): Průvodce po archivních fondech, Státní archiv Brno. Archivní správa ministerstva vnitra, Praha, 363 pp.

VONDRUŠKA, V. (1989): Základní rysy zemědělské výroby v Čechách v letech 1781-1848. Hospodářské dějiny, 17, pp. 7-69.

VOTRUBA, L., PATERA, A. (2004): Povodně v Čechách v dílech českých historiků a kronikářů (11.-19. století). Český svaz vědeckotechnických společností, Praha, 38 pp.

WETTER, O., PFISTER, C. (2011): Spring-summer temperatures reconstructed for northern Switzerland and southwestern Germany from winter rye harvest dates, 1454-1970. Climate of the Past, 7, No. 4, pp. 1307-1326.

ZAHRADNÍČEK, P. (2005): Archivní zprávy o škodách způsobených živelnými pohromami jako zdroj údajů pro studium hydrometeorologických extrémů a jejích dopadů na př́kladu panství Bítov. Master thesis. Masarykova univerzita v Brně, Př́rodovědecká fakulta, 120 pp.

\section{Archival sources}

S1: Moravský zemský archiv Brno, fond F 16 Velkostatek Brtnice (1537) 1562-1947 (1963), inv. č. 277 , fol. $23 \mathrm{rv}$.

S2: See S1, inv. č. 283 , fol. $1 \mathrm{r}-22 \mathrm{v}$.

S3: See S1, inv. č. 371, fol. 34rv.

S4: See S1, inv. č. 371, fol. 53rv.

S5: See S1, inv. č. 371 , fol. $66 \mathrm{rv}$.

S6: See S1, inv. č. 371 , fol. 106rv, 111r-112v, 114rv, 118r-119v.

S7: See S1, inv. č. 371, fol. 134rv.

S8: See S1, inv. č. 371, fol. 150rv.

S9: See S1, inv. č. 371 , fol. $248 \mathrm{r}-249 \mathrm{v}$.

S10: See S1, inv. č. 371, fol. 270rv.

S11: See S1, inv. č. 371, fol. 310rv, 328r, 348rv.

S12: See S1, inv. č. 371, fol. 327rv, 338rv, 371r.

S13: See S1, inv. č. 371 , fol. $348 \mathrm{r}-350 \mathrm{v}$.

S14: See S1, inv. č. 403 , fol. 2 r-15r.

S15: See S1, inv. č. 485 , fol. 42rv, 52rv, 70rv.

S16: Moravský zemský archiv Brno, fond F 61 Velkostatek Křižanov (1437) 1641-1945, inv. č. 82 , fol. $2 \mathrm{rv}, 7 \mathrm{rv}, 11 \mathrm{rv}$.

S17: See S16, inv. č. 82, fol. 59rv.

S18: See S16, inv. č. 82, fol. 99r-109v.

S19: Moravský zemský archiv Brno, fond F 143 Velkostatek Budišov 1629-1945, inv. č. 239, fol. $274 \mathrm{r}-276 \mathrm{v}$.

S20: See S19, inv. č. 240 , fol. $37 \mathrm{r}-48 \mathrm{v}$.

S21: See S19, inv. č. 240, fol. 230rv.

S22: Moravský zemský archiv Brno, fond F 178 Velkostatek Nové Město na Moravě 1500-1954, inv. č. 1045 , fol. $156 \mathrm{r}-160 \mathrm{r}$. 
S23: Moravský zemský archiv Brno, fond F 182 Velkostatek Osová (1570) 1573-1946, inv. č. 180, fol. 111rv, 113rv.

S24: See S23, inv. č. 180, fol. 128rv.

S25: See S23, inv. č. 180 , fol. $302 \mathrm{r}-306 \mathrm{v}$.

S26: See S23, inv. č. 180 , fol. 383rv, 385rv, 388r-401r.

S27: See S23, inv. č. 281, fol. 1r-5v.

S28: See S23, inv. č. 281, fol. 32rv.

S29: Moravský zemský archiv Brno, fond F 200 Velkostatek Třebíč (1335) 1538-1949, inv.

č. 542 , fol. 132 r-232r.

S30: See S29, inv. č. 542, fol. 279rv.

S31: See S29, inv. č. 666 , fol. 2r-5r, 15r-20r.

S32: See S29, inv. č. 666, fol. 3r, 12rv.

S33: See S29, inv. č. 666 , fol. 10rv.

S34: See S29, inv. č. 667, fol. 154rv.

S35: See S29, inv. č. 667, fol. 211rv, 216rv, 219rv, 221r.

S36: See S29, inv. č. 667, fol. 260rv.

S37: Moravský zemský archiv Brno, fond F 209 Velkostatek Velké Meziříčí (1448) 1613-1948, inv. č. 377 , fol. $66 \mathrm{r}$.

S38: SOkA Žd’ár nad Sázavou, fond Farní a děkanský úřad Velké Meziříčí 1671-1964, inv. č. 112.

\section{Shrnutí}

\section{DOPADY HYDROMETEOROLOGICKÝCH EXTRÉMŮ NA ČESKOMORAVSKÉ VRCHOVINĚ V OBDOBÍ 1706-1889 PODLE DAŇOVÝCH ZÁZNAMŮ}

Škody způsobené hospodářrum hydrometeorologickými extrémy na jejich polnostech a majetku byly na Moravě od poloviny 17. století důvodem pro snížení výše daní. Složitý administrativní proces daňové bonifikace vyžadoval řadu dokumentů (obr. 2) na úrovni obcí, krajských úřadů i celé země, z nichž mnohé zůstaly dochovány v archivních fondech. V nich je obsažena řada informací o hydrometeorologických extrémech a jejich dopadech.

Tato studie analyzuje dopady hydrometeorologických extrémů pro sedm velkostatků (Brtnice, Budišov, Křižanov, Osová, Petráveč, Třebíč a Velké Meziříčí) ve střední části Českomoravské vrchoviny (obr. 1). Během studovaného období 1706-1889 bylo popsáno celkem 133 případů hydrometeorologických extrémů (obr. 3a), které byly nejčastěji reprezentovány př́valovými dešti, krupobitími a bleskovými povodněmi, zpravidla $\mathrm{v}$ jejich kombinaci (obr. 3b). Hydrometeorologické extrémy byly zaznamenány celkem v 70 rocích studovaného období (nejvíce šest událostí v roce 1830). Nejvíce postižených obcí v jednom roce bylo zjištěno v roce 1827 (40), následovaném roky 1756 (37) a 1820 (31; obr. 3c). V návaznosti na přírodní podmínky studované oblasti hrály v její západní části hlavní roli bleskové povodně z přívalových srážek, zatímco ve východní části působilo škody hlavně krupobití. Pro pět velkostatků zůstaly dochovány počty postižených obcí (obr. 4a) a výše poskytnuté daňové úlevy (obr. 4b) pro období 1822-1846. Nejextrémnější událostí bylo krupobití ze dne 25. června 1844, kdy byla sleva na dani poskytnuta 25 obcím ve výši 5302 zlatých.

Těžiště práce spočívá ve studiu dopadů hydrometeorologických extrémů na zemědělství a rostlinnou produkci, na majetek a na sociálně-ekonomickou stránku života hospodářru. V první skupině jsou popsány dopady na pole a úrodu (potlučení, zaplavení nebo zanesení polí a úrody, eroze půdy, snížené výnosy), na louky a pastviny (zanesení, přemodelování ŕičních niv a snížení produkce sena) a na hospodářská zvířata (úhyn zvířat, nucené snížení stavu kvůli nedostatku krmiva). Škody na polích a lukách ústily do zvýšeného finančního zatížení hospodářů a následného nedostatku financí vedoucího mimo jiné k chudobě, zadluženosti a snížení investic do hospodářství (obr. 5). Druhá skupina dopadů je reprezentována zaplaveným movitým i nemovitým majetkem, zničenými komunikacemi, strženými mosty, vyhořelými budovami včetně uskladněné úrody nebo kroupami poničenou střešní krytinou. Škody z předchozích dvou oblastí se promítaly do socio-ekonomických dopadů reprezentovaných 
zadlužením hopodářů (po špatné úrodě), problémy se splácením finančních půjček a jejich úroků a poklesem životní úrovně. Vedle slevy na pozemkové a příplatkové dani přispívaly ke zmírnění škod i půjčky z kontribučních fondů a sýpek, finanční sbírky, sbírky obilí a také přímá pomoc vrchnosti. Pomoc postiženým byla ale nezřídka komplikována administrativními průtahy, časovými prodlevami a stížnostmi.

Předložená studie je nová zaměřením na studium dopadů hydrometeorologických extrémů na základě daňových záznamů, které byly dosud využity pouze pro studie s hydrometeorologickým zaměřením. Bude sloužit jako metodologický základ pro studium dopadů uvedených extrémů na celé jižní Moravě v průběhu 17.-19. století.

Obr. 1 -Studovaná oblast s vyznačenými katastry velkostatků Brtnice, Budišov, Křižanov, Osová, Petráveč, Třebíč a Velké Meziříčí podle stavu v roce 1849 (A-D značí katastry patřící ke vzdálenějším velkostatkům) a místa citovaná v textu: 1 - Benetice; 2 Bransouze; 3 - Červená Lhota; 4 - Číchov; 5 - Dolní Smrčné; 6 - Horní Radslavice; 7 - Hynkov; 8 - Chlístov; 9 - Kamenice; 10 - Kamenička; 11 - Kněžice; 12 - Komárovice; 13 - Kožichovice; 14 - Krahulov; 15 - Markvartice; 16 - Martinice; 17 - Milešín; 18 - Mostiště; 19 - Nárameč; 20 - Okříšky; 21 - Ořechov; 22 - Osová Bítýška; 23 - Petrovice; 24 - Pokojovice; 25 - Pozdátky; 26 - Přibyslavice; 27 - Přímělkov; 28 - Příseka; 29 - Skřináŕov; 30 - Sokolí; 31 - Stř́ižov; 32 - Uhřínovice; 33 - Víckov

Obr. 2 -Daňový záznam týkající se škod krupobitím dne 27. srpna 1845 v obci Kamenice (S30)

Obr. 3 -Četnosti hydrometeorologických extrémů na sedmi velkostatcích na Českomoravské vrchovině v období 1706-1889: (a) celkem, (b) četnost typů hydrometeorologických extrémů, (c) počet postižených obcí

Obr. 4 - Počet obcí postižených krupobitím (a) a přiznaná daňová bonifikace (b) pro velkostatky Budišov, Křrižanov, Osová, Třebíč a Velké Meziříčí v období 1822-1846 (S20)

Obr. 5 -Model dopadů hydrometeorologických extrémů na pole a louky ve studované oblasti

Authors' affiliation: L. Dolák and R. Brázdil: Masaryk University, Institute of Geography, Kotlářská 2, 61137 Brno, and Global Change Research Centre, Academy of Sciences of the Czech Republic, Bělidla 956/4a, 60300 Brno, Czechia; e-mail: dolak@mail.muni.cz, brazdil@sci.muni.cz. H. Valášek: Moravian Land Archives, Palachovo nám. 1, 62500 Brno, and Masaryk University, Institute of Geography, Kotlářská 2, 61137 Brno, Czechia, e-mail: valasek@mza.cz.

Initial submission, 9 October 2014; final acceptance 23 May 2015.

\section{Please cite this article as:}

DOLÁK, L., BRÁZDIL, R., VALÁŠEK, H. (2015): Impacts of hydrometeorological extremes in the Bohemian-Moravian Highlands in 1706-1889 as derived from taxation records. Geografie, 120 , No. 4, pp. 465-488. 